Bartın Üniversitesi

Eğitim Fakültesi Dergisi

Cilt 6, Sayı 1, s. 68-84, Şubat 2017

BARTIN - TÜRKIYE

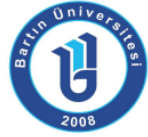

ISSN: 1308-7177
Bartin University

Journal of Faculty of Education

Volume 6, Issue 1, p. 68-84, February 2017

BARTIN - TURKEY

\title{
Sosyobilimsel Konu İçerikli Alan Gezilerinin Illköğretim Öğrencilerinin Argümantasyon Nitelikleri Üzerine Etkisi
}

Mustafa Sami TOPÇU, Doç. Dr., Yıldız Teknik Üniversitesi Eğitim Fakültesi, msamitopcu@gmail.com
Nejla ATABEY, Yrd. Doç. Dr., MuşAlparslan Üniversitesi, Eğitim Fakültesi, Okul Öncesi Eğitimi, nejlakaya82@gmail.com

Öz: Bu araştırmada, sosyobilimsel konu içerikli alan gezilerinin ilköğretim öğrencilerinin argümantasyon nitelikleri üzerindeki etkisi araştırılmıştır. Çalışma grubunu, 7. sınıfta öğrenim gören 31 ilköğretim öğrencisi oluşturmaktadır. Tek grup ön test son test modeli kullanılan araştırmada termik, rüzgâr ve hidroelektrik santrallerine alan gezileri düzenlenmiştir. Araştırma verileri santral gezileri öncesinde ve sonrasında bireysel olarak tamamlanan yazılı argümantasyon formları ile toplanmıştır. Yazılı argümantasyon formları argümantasyon rubriğine göre analiz edilmiştir. Verilerin analizi,alan gezileri sonrasında üst seviyede iddia, kanıt ve muhakeme sunan öğrenci sayısının yükseldiğini ortaya koymuştur. Bu bulgulara dayanarak sosyobilimsel konu içerikli alan gezilerinin öğrencilerin üst düzey düşünme becerilerinden olan argümantasyon yeteneklerini geliştirdiği tespit edilmiştir. Araştırmanın öğretmenlere ve araştırmacılara fen bilimleri ve çevre eğitiminde sosyobilimsel konu içerikli alan gezilerinin düzenlenmesi noktasında rehberlik edeceği düşünülmektedir.

Anahtar Kelimeler: sosyobilimsel konular, alan gezisi, argümantasyon, ilköğretim öğrencileri

\section{The Effect of Socioscientific Issues Based Field Trips on Elementary School Students' Argumentation Quality}

\begin{abstract}
In this study, the effect of socioscientific issues based field trips on students' argumentation quality was investigated. The participants were 31 seventh grade students. One group pre-test post-test model was used. Field trips to thermal, wind and hydroelectric power plants were conducted. Students developed scientific models related to power plants and completed written argumentation forms individually. These forms were evaluated according to the argumentation rubric. Results showed that students could present their claims at the second level before and after field trips. We also determined a decrease in the number of students presenting evidence at the first level and an increase in the number of students presenting the second and third level of evidence and reasoning. We may claim that socioscientific issues based field trips could improve students' argumentation quality. We also suppose that this study would guide teachers, researchers in terms of implementation of socioscientific issues based field trips.
\end{abstract}

Key Words: socioscientific issues, field trips, argumentation, elementary school students

\footnotetext{
Bu çalışma, TÜBITAK 4004 programı kapsamında 113B098 No'lu proje olarak TÜBiTAK tarafından desteklenmiştir. Bu destekten dolayı TÜBITAK'a teşekkür ederiz.
} 


\section{GiRiş}

Günümüzde bilimsel uygulamaların etkisiyle dünya hızla değişmekte ve gelişmektedir. Bu gelişmeler beraberinde bazı problemleri de getirmektedir. Hava, toprak ve su kirlilikleri bu problemlerden bazılarıdır. Çevre kirliliklerine birçok sebep gösterilmekle beraber en önemli nedenlerden biri enerji ihtiyacını karşılamak için kurulan santrallerin yaydığı zehirli gazlar olarak açıklanmaktadır. Bu nedenle enerji ihtiyacını karşılamak için çevreye zarar vermeyen veya minimum düzeyde zarar veren yenilenebilir enerji kaynakları çözüm olarak görülmektedir. Birçok ülkede hidroelektrik, nükleer ve rüzgâr enerji santrallerinin kurulması gündeme gelmektedir. Ancak bu santrallerinin kurulması toplumların bazı kesimleri tarafından desteklenmekte iken bazı kesimlerince onaylanmamaktadır. Örneğin bir grup insan nükleer enerji santrallerinin kurulmasını yeşil alanların yok olması, radyoaktif atıkların çevreye yayılması ya da habitatlarının zarar görmesi gerekçeleri ile savunmamakta iken bir grup insan iş imkânı sağlaması nedeniyle bu santrallerinin kurulmasını desteklemektedir.

Toplumda farklı bakış açıları ile değerlendirilebilen, fayda ve zarar analizlerini içeren, bilimsel temelleri olan bu konulara sosyobilimsel konular denilmektedir (Sadler, 2004; Topcu, 2015). Sosyobilimsel konular toplumu yakından ilgilendiren, tartışmalı, farklı bakış açılarını kapsayan (Eastwood, Sadler, Zeidler, Lewis, Amiri ve Applebaum, 2012), ahlaki, etik, siyasi ve bilimsel boyutlara sahip olan konulardır (Yahaya, Zain ve Karpudewan, 2012). Günümüzde genetiği değiştirilmiş organizmalar, klonlama ve aşı gibi birçok sosyobilimsel konu ile karşı karşıya kalmaktayız. Bu konularla karşılaşan bireylerin fayda ve risk analizleri yapabilmesi, konuyla ilgili karar verebilmesi, düşüncelerini kanıt ve muhakemelerle savunabilmesi beklenmektedir. Bireylerin bu becerileri kazanabilmesi için sosyobilimsel konuların eğitimöğretim faaliyetlerine katılması gerektiği düşünülmektedir. Ulusal Araştırma Konseyi (NRC) ve Bilimsel Gelişme için Amerikan Birliği (AAAS) gibi dünyada kabul gören önemli fen eğitimi araştırma merkezleri sosyobilimsel konuların fen eğitiminde önemli olduğuna ve yer alması gerektiğine vurgu yapmaktadır. Örneğin NRC (1996), bireylerin bilimsel ve teknolojik konular hakkında gerçekleşen toplumsal tartışmalarda düşüncelerini savunabilme yeteneğine sahip olması gerektiğini belirtmiştir. AAAS (1990) de modern fen eğitiminin en önemli hedeflerinden biri olarak sosyobilimsel konuların öğretimini göstermiştir. Eğitimde sosyobilimsel konulara yapılan vurguya rağmen bu konuların sınıf ortamlarında sınırlı bir şekilde kullanıldığı tespit edilmiştir. Bu duruma iki ana gerekçe gösterilmektedir: SBK-içerikli öğretimle ilgili müfredat materyallerinin yeterli olmaması ve öğretmenlerin bu uygulamalar açısından yeterince desteklenmemesi (Hofstein ve Bybee, 2011). Literatürde özellikle sosyobilimsel konu içerikli öğretimlerin nasıl tasarlanabileceği ve uygulanabileceği konusunda öğretmenlere örnek olabilecek çalışmalar açısından eksiklik mevcuttur (Sadler, Friedrichsen, Graham, Foulk, Tang ve Menon, 2015; Topçu, 2015). Bu eksiklikler SBK içerikli öğrenme ortamlarının geliştirilmesini konu alan yeni araştırmaları gerekli kılmaktadır.

Alan gezileri bu noktada sosyobilimsel konuların eğitim-öğretim faaliyetlerine dâhil edilebilmesi için uygun ortamlar sunabilir. Alan gezilerinin öğrencilere gerçek yaşam deneyimleri sunduğu (Shakil, Faizi ve Hafeez, 2011) göz önünde bulundurulur ise bu geziler sosyobilimsel konularla öğrencilerin yüzleşmesini sağlamak için kullanılabilir. Böylece öğrencilerin gerçek yaşama hazırlanmaları da desteklenecektir. Alan gezileri sürecinde gerçekleştirilen etkinliklerde öğrenciler var olan bilgilerini günlük yaşamla ilişkilendirebilmekte, 
konunun olumlu ve olumsuz etkilerini yerinde görebilmekte ve uzman açıklamaları ile konuyla ilgili bilgilerini destekleyebilmektedir (Topçu ve Atabey, 2014). Sosyobilimsel konuyla ilgili problemin anlaşııması, düşüncelerin savunulması açısından önem arz etmektedir. Alan gezilerinin hedeflenen içeriğin anlaşılması ve öğrenilmesi üzerinde olumlu etkiye sahip olduğu birçok çalışma tarafından da ortaya konmuştur. Örneğin Taş (2012) tarafından yapılan çalışmada katılımcılar alan gezilerinin doğal ortamlarda yaparak-yaşayarak öğrenmeyi, teori ve uygulama arasındaki farkı anlamayı desteklediğini belirtmiştir. Shakil, Faizi ve Hafeez (2011) tarafından yapılan çalışmanın katılımcıları da eğitsel alan gezilerinin öğrenme problemleri ile başa çıkmayı kolaylaştırdığını, uygulamaya dönük etkinlikler sunduğunu ve öğrenmeyi ilgi çekici hale getirdiğini belirtmiştir. Bu bulgular ışığında sosyobilimsel konu içerikli alan gezilerinin fen öğrenmeyi ilgi çekici hale getirmenin yanı sıra öğrencilerin bilişsel gelişimini de pozitif yönde etkileyeceği düşünülmektedir.

Sosyobilimsel konunun anlaşılması, konuyla ilgili karar vermeyi de beraberinde getirecektir. Ayrıca sosyobilimsel problemi anlayan bireyler konuyla ilgili kararlarını daha nitelikli bir şekilde savunabilecektir. Bir konudaki fikirleri uygun bilgi ve gerekçelerle savunma literatürde "argümantasyon" olarak tanımlanmaktadır (Toulmin, 1958). Argümantasyon bir başka tanımda, mantıklı bir yargıya varmadan önce sahip olunan fikirlerin dinleyici ya da okuyucular tarafından kabul edilebilirliğini arttırmayı amaçlayan akıl yürütme olarak açıklanmaktadır (van Eemeren, Grootendorst ve Henkemans, 1996). Fen eğitiminde sosyobilimsel konulara verilen öneme benzer bir şekilde argümantasyona da vurgu yapılmaktadır (Naylor, Keogh ve Downing, 2007). Argümantasyonun farklı eğitim değişkenleri üzerindeki olumlu etkisi bu vurgunun nedeni olabilir. Literatürde argümantasyonun öğrencilerin muhakeme (Rebello ve Barrow, 2013), karar verme (Dawson ve Venville, 2010), sınıf dışındaki ortamlarda akıl yürütme (McNeill ve Krajcik, 2009), bilimsel düşünme ve kavramsal anlama (Zohar ve Nemet, 2002) yeteneklerini geliştirdiği ve öğrenci merkezli etkinlikler sunduğu (Yaman, 2011) belirtilmektedir. Sosyobilimsel konuların tartışmalı yapısı nedeniyle bu konularda öğrencilerin karar verme ve muhakeme yeteneklerinin gelişmesi önemlidir. Argümantasyonun bu yetenekleri geliştirdiği göz önünde bulundurulur ise sosyobilimsel konuların ele alınmasında argümantasyonun uygun ve etkili bir strateji olduğu söylenebilir. Sadler (2004) da sosyobilimsel konuların öğrencilerin argümantasyon yetenekleri ile donatılabileceği uygun içerikler sunduğunu belirtmiştir. Literatürde sosyobilimsel konularla ilgili yapılan çalışmaların çoğunun argümantasyon üzerine yoğunlaştığı görülmektedir (Topçu, Muğaloğlu ve Güven, 2014). Ancak öğrencilerin argümantasyon niteliklerinin hala istenilen düzeyde olmadığını ortaya koyan çalışmalar mevcuttur (Knight ve McNeill, 2012). Örneğin öğrencilerin argümanlarında bilgi ve gerekçelerle iddialarını desteklemekten çok sadece iddialarda bulunduğu (Jime'nez-Aleixandre, Rodriguez ve Duschl, 2000), iddiaları için yeterli kanıt sunmakta başarısız oldukları (Sandoval ve Millwood, 2005), iddia ve kanıtı bağlamalarına imkân veren bilimsel ilkeleri nadiren ifade ettikleri (McNeill, Lizotte, Krajcik ve Marx, 2006) belirtilmektedir. Öğrencilerin argümantasyon niteliklerinin istenilen düzeye geliştirilebilmesi için argümantasyon sürecini destekleyen yeni uygulamalar kullanılması gerekmektedir.

Sosyobilimsel konu içerikli alan gezilerinin bu noktada destekleyici bir uygulama olacağı düşünülmektedir. Bu nedenle mevcut çalışmada sosyobilimsel konu içerikli alan gezilerinin öğrencilerin argümantasyon nitelikleri üzerindeki etkisi araştırılmıştır. Literatürde sosyobilimsel konu içerikli alan gezileri ve argümantasyon niteliği arasındaki ilişkiyi araştıran çalışma sayısının yetersiz olduğu tespit edilmiştir. Dolayısıyla çalışmanın hem sosyobilimsel konu içerikli alan gezilerinin eğitim öğretim faaliyetlerine dahil edilmesi hem de argümantasyon niteliğinin alan gezisi gibi farklı bir uygulama ile desteklenmesi açısından örnek teşkil edeceği düşünülmektedir. Bu kapsamda mevcut çalışmaya yön veren araştırma sorusu "Sosyobilimsel konu içerikli alan gezilerinin ilköğretim 7. sınıf öğrencilerinin argümantasyon nitelikleri 
üzerinde etkisi nedir?" şeklindedir. Bu soruya cevap bulmak için kullanılan yöntem aşağıda açıklanmıştır.

\section{YÖNTEM}

Araştırmada kullanılan tek grup ön test-son test modeli kapsamında tek bir grup ile çalışılmakta ve bu gruba uygulama öncesinde ve sonrasında ölçmeler yapılmaktadır (Karasar, 2000). Sunulan araştırma TÜBITAK 4004 projesi kapsamında gerçekleştirilmiş olup, tüm etkinlikler 2010-2011 eğitim-öğretim yılından sonraki yaz tatili döneminde tamamlanmıştır. Bu nedenle sadece bir grup öğrenci ile çalışılabilmiştir. Çalışma sonuçları bu sınırılık göz önüne alınarak değerlendirilmiştir.

Bundan sonraki bölümde araştırmanın katılımcıları, veri toplama araçları ve veri analizi ile ilgili bilgiler verilmiştir.

\section{1. Çalışma Grubu}

Araştırma Muğla il Merkezi içinde iki devlet ortaokulunda öğrenimlerine devam etmekte olan 7. sınıf öğrencileri ile gerçekleştirilmiştir. Katılımcılar belirlenmeden önce farklı okul idareleriyle, velilerle ve öğrencilerle iletişime geçilmiş, bu kişilere çalışma hakkında bilgi verilmiştir. Gönüllü olan ve veli izni alınan 31 öğrenciyle (17'si kız, 14'ü erkek) araştırma gerçekleştirilmiştir. Araştırmaya katılan öğrencilerin yaş aralığı 12-13 olup, bu öğrencilerin cinsiyet özellikleri Tablo 1' de verilmiştir.

Tablo 1

Katılımcıların Cinsiyetleri

\begin{tabular}{cccc}
\hline \multicolumn{1}{c}{ Değişken } & Tür & Frekans & Yüzde \\
\hline Cinsiyet & Erkek & 14 & 45,16 \\
& Kız & 17 & 54,83 \\
& Toplam & 31 & \\
\hline
\end{tabular}

Tablo 1'deki veriler incelendiğinde demografik özellikler açısından araştırmaya katılan öğrencilerin \% 45,16 erkek ve \% 54,83 oranında kız öğrencilerden oluştuğu görülmektedir. Ayrıca araştırmaya katılan öğrenciler daha önce herhangi bir alan gezisine katılmadıklarını ve argümantasyon stratejisini kullanmadıklarını belirtmiştir.

\subsection{Veri Toplama Araçları}

Çalışmanın verileri araştırmacılar tarafından hazırlanan yazılı argümantasyon formları kullanılarak toplanmıştır. Yazılı argümantasyon formları sosyobilimsel konu içeren bir metin ve metnin ardından öğrencilerin argüman öğelerini sunmalarını gerektiren sorulardan oluşmaktadır. Araştırma sürecinde Yatağan Termik Santrali, Datça Dares Rüzgâr Santrali ve Dalaman Akköprü Hidroelektrik Santrali olmak üzere üç enerji santraline gezi düzenlenmiştir. Her enerji santraline özel yazılı argümantasyon formu hazırlanmıştır. Bu nedenle toplamda üç farklı yazıı ırgümantasyon formu kullanılmıştır. Örnek bir yazılı argümantasyon formu ekte sunulmuştur. Formların geçerlik ve güvenirlik çalışması araştırmacılar tarafından yapılmıştır. Hazırlanan metinler ve sorular içerik bilgisi açısından bir Fen Bilimleri öğretmeni, sosyobilimsel konu özellikleri açısından bu konuda uzman olan bir öğretim üyesi, dil bilgisi kuralları ve anlaşılabilirlik açısından da bir Türkçe öğretmeni tarafından incelenmiştir. Ardından 7. sınıfta 
öğrenim gören 25 öğrenciye pilot çalışma olarak uygulanarak alınan geri dönütler doğrultusunda gerekli düzeltmeler yapılmıştır.

Yazılı argümantasyon formları araştırma sürecinde termik, rüzgâr ve hidroelektrik santrallerine düzenlenen alan gezilerinden önce ve sonra öğrencilere dağıtılmış, öğrencilerce bu formlar doldurulmuştur. Her santrale ait olan ön ve son yazılı argümantasyon formları iddia, kanıt ve muhakeme öğeleri açısından karşılaştırıımıştır. Böylece sosyobilimsel içerikli alan gezilerinin öğrencilerin argümantasyon niteliklerini nasıl etkilediği ortaya konmaya çalışımıştır.

\subsection{Uygulama Süreci}

Araştırma sürecinde ilk olarak öğrencilerin termik santralleri ile ilgili düşüncelerini ve farkındalıklarını tespit etmek amacıyla yazılı argümantasyon formu uygulanmıştır. Ardından ilk alan gezisi Muğla-Yatağan Termik Santrali'ne düzenlenmiştir. Santral içerisindeki farklı bölümlere gerçekleştirilen gezi boyunca mühendisler, öğrencilere elektrik üretim sürecini anlatmıştır. Örneğin termik santralinin çalışması için gerekli olan ısı enerjisinin kömürden elde edildiği, bu amaçla her gün yakılan kömür miktarı ve oluşan kül miktarı, küllerin nasıl ve nerede biriktirildiği, havaya salınan gazların özellikleri ve miktarları gibi detaylı bilgiler öğrencilere önce bir slayt gösterisi ardından santral içi geziler ile açıklanmıştır. Ardından termik santrallerinin çevre üzerindeki etkisini araştırmak amacıyla santral çevresinden toprak örnekleri alınmıştır. Alınan bu örnekler Muğla Sıtkı Koçman Üniversitesi Fen Bilimleri laboratuvarlarında kimya alanında uzman bir öğretim üyesi ve ekibi tarafından analiz edilmiştir. Öğrencilerin çevreyle ilgili olumlu tutum kazanmalarını desteklemek amacıyla santral çevresinde ağaçlandırma etkinliği gerçekleştirilmiştir. Alan gezisinin tamamlanmasının ardından Muğla Sıtkı Koçman Üniversitesi Eğitim Fakültesi laboratuvarlarında öğrenciler gruplar halinde termik santrali modellerini tamamlamıştır. Tüm etkinliklerin ardından çalışma başında uygulanan yazılı argümantasyon formu son test olarak tekrar öğrencilerce tamamlanmıştır.

İkinci alan gezisi rüzgar enerji santraline düzenlenmiştir. Gezi öncesinde öğrenciler araştırmacılar tarafından rüzgar santrali için hazırlanan yazılı argümantasyon formunu tamamlamıştır. Ardından alan gezisi gerçekleştirilmiş ve gezi boyunca ilgili mühendisler rüzgar santrallerinin çalışma prensibi, bu santrallerin çevre ve yaşam alanları üzerindeki etkileri gibi konuyla ilgili farklı boyutlarda bilgiler vermiştir. Santral içerisindeki gezinin tamamlanmasının ardından santral çevresinden toprak numuneleri alınmış ve uygun görülen bir alanda ağaçlandırma yapıımıştır. Alınan numuneler üniversite laboratuvarlarında analiz edilmiştir. Ardından öğrenciler gruplar halinde rüzgar santrali modellerini tasarlayıp, çalıştırmıştır. Son olarak gezi öncesinde tamamlanan yazılı argümantasyon formu öğrenciler tarafından tekrar doldurulmuştur.

Üçüncü alan gezisi hidroelektrik enerji santraline düzenlenmiştir. Diğer santrallerde olduğu gibi gezi öncesinde araştırmacılar tarafından hidroelektrik enerji santrali için hazırlanan yazılı argümantasyon formu öğrencilerce doldurulmuştur. Takiben alan gezisi gerçekleştirilmiş ve uzmanlarca hidroelektrik enerji santrallerinin çalışma prensibi, kurulma alanlarındaki canlı yaşamları üzerindeki etkisi gibi farklı içeriklerde açıklamalarda bulunulmuştur. Alan gezisinin tamamlanmasının ardından santral çevresinden toprak numuneleri alınmış ve uygun görülen bir alana öğrenciler tarafından ağaç fideleri dikilmiştir. Toprak numuneleri bir kimya mühendisi ve ekibi tarafından analiz edilmiş ve sonuçlar öğrencilerce yorumlanmıştır. Ardından öğrenciler gruplar halinde hidroelektrik enerji santrali modellerini tasarlamış ve çalıştırmıştır. Son olarak gezi öncesinde tamamlanan yazılı argümantasyon formu tekrar öğrencilerce doldurulmuştur.

Enerji santrallerine düzenlenen alan gezileri kapsamında gerçekleştirilen etkinlikler şu şekilde özetlenebilir: Yazılı argümantasyon formlarının tamamlanması, enerji santrallerine alan gezisi düzenlenmesi, santral içerisinde gerçekleştirilen gezi boyunca konu uzmanları tarafından 
elektirik üretim sürecinin açıklanması, santral çevresinden toprak numunelerinin alınması ve ağaçlandırma etkinliği, üniversite laboratuvarlarında toprak örneklerinin uzman ekip tarafından analiz edilmesi, öğrencilerin gruplar halinde santral modelleri tasarlaması, yazılı argümantasyon formlarııı tekrar tamamlanması.

Alan gezileri ve araştırma boyunca tamamlanan etkinlikler ile öğrencilerin enerji santrallerinin kurulmasına yönelik argümanlarının desteklenmesi amaçlanmıştır. Sosyobilimsel konu hakkında sahip olunan ön bilgilerin ve deneyimlerin argüman kalitelerini etkilediği farklı çalışmalar ile ortaya konmuştur (Sadler ve Donnelly, 2006). Bu nedenle öğrencilerin enerji santrallerinin kurulması ile ilgili temel bilgilere sahip olmasına yönelik etkinlikler tasarlanmıştır. Enerji santrallerine düzenlenen alan gezilerinde mühendisler öğrencilere enerji üretim sürecini açıklamıştır. Örneğin hidroelektrk enerji santrallerinde enerji kaynağı olarak suyun kullanıldığı, suyun nehir ve ya akarsu gibi akış halindeki kaynaklarının önüne kurulan setlerde biriktirildiği, bu durumun su canlılarının yaşamı ve baraj çevresindeki yaşam alanları üzerindeki etkisi, baraj kurulumunun getirdiği jeolojik dezavantajlar yanısıra çevre üzerindeki olumlu etkileri gibi farklı boyutlar hakkında açıklamalar yapılmıştır. Öğrencilerin argümanlarını en iyi şekilde savunabilmesi için farklı argümanları öngörebilmesi, konunun avantaj ve dezavantajlarını ele alabilmesi de önemlidir (Aktamış ve Hiğde, 2015). Bu nedenle enerji üretim süreci hakkında yapılan bilgilendirilmeler ile sınırlı kalınmamış, santral çevrelerinden toprak numuneleri alınmıştır. Bu numuneler laboratuvar koşullarında analiz edilip yorumlanmıştır. Böylece enerji üretiminin çevre üzerindeki etkilerinin keşfedilmesi amaçlanmıştır. Bunun yanısıra bir enerji santralinin kurulması ve işlenmesi sürecinde farklı meslek dallarının görev aldığının ve bir istihdam sağlandığının fark edilmesi amacıyla öğrenciler enerji santrali modellerini tasarlayıp, çalıştırmışlardır. Alan gezisi boyunca yapılan bu etkinlikler ile öğrencilerin enerji santrallerinin kurulmasına yönelik argümanlarını daha üst seviyede kanıt ve muhakemeler ile savunabilmesi amaçlanmıştır. Alan gezilerinin öğrencilere sosyobilimsel konu ile ilgili gerçek hayat deneyimleri kazanma, sosyobilimsel konuyu yerinde gözlemleme imkanı sağlayacağı böylece öğrencilerin konuyu çok boyutlu değerlendirebileceği ve çeşitli argümanlar sunabileceği düşünülmüştür.

\subsection{Verilerin Analizi}

Araştırma verileri yazılı argümantasyon formları ile toplanmıştır. Termik, hidroelektrik ve rüzgâr santrallerine düzenlenen alan gezileri öncesinde ve sonrasında öğrencilerce tamamlanan yazılı argümantasyon formları McNeill (2011) tarafından geliştirilen argümantasyon rubriğiyle değerlendirilmiştir. Bu rubrik farklı çalışmalarda argümantasyon niteliğinin değerlendirilmesi amacıyla kullanılmıştır (Atabey ve Topçu, 2013; Berland ve Reiser, 2009; Ekiz, Topçu ve Aydeniz, 2013; McNeill ve Krajcik, 2009). Bu rubriğe göre bir argümanın niteliğine iddia, kanıt ve muhakeme öğelerinin varlığı ve özelliklerine göre karar verilmektedir. Argüman öğeleri ve bu öğelerin özelliklerini McNeill ve Martin (2013) çalışmasında şu şekilde açıklamıştır. İddia, bir soruya verilen cevap ya da çıkarım olarak tanımlanmakta ve öğrencilerin ifade etmekte en az zorlandıkları öğe olarak belirtilmektedir. Kanıt, gözlem ya da ölçümler sonucunda elde edilen ve iddiayı destekleyen veri olarak açıklanmaktadır. Muhakeme ise iddia ve kanıt arasında bağlantı kuran savunmalar olarak tanımlanmakta ve çerçevedeki en zor öğe olarak ifade edilmektedir. Kanıt ve iddia öğelerinin uygun ve yeterli olması gerektiği de belirtilmektedir. Bu öğelerin uygun olması içeriğin bilimsel açıdan doğru olması, yeterli olması ise iddiayı desteklemek ya da savunmak için yeterli veri sunmak şeklinde açıklanmaktadır. Her bir öğe 0 ve 2 puan arasında değerlendirilmekte olup, 0 puan en düşük niteliği 2 puan en yüksek niteliği temsil etmektedir. Mevcut çalışmada kullanılan bu rubriğe ait özellikler Tablo 2'de verilmiştir. 
Tablo 2

Argümantasyon Niteliği Rubriği (McNeill, 2011)

\begin{tabular}{|c|c|c|c|}
\hline $\begin{array}{l}\text { Argümantasyon } \\
\text { Bileşenleri }\end{array}$ & $\begin{array}{l}\text { Iddia } \\
\text { (Soruya cevap veren } \\
\text { bir durum ya da } \\
\text { çıkarım) }\end{array}$ & $\begin{array}{l}\text { Kanıt } \\
\text { (İddiayı destekleyen } \\
\text { yeterli ve uygun veri) }\end{array}$ & $\begin{array}{c}\text { Muhakeme } \\
\text { (Kanıt iddiayı nasıl ve } \\
\text { niçin destekler) }\end{array}$ \\
\hline 1 & $\begin{array}{l}\text { Açıklamalar bir iddia } \\
\text { içermez ya da yanlış } \\
\text { iddia içerir. }\end{array}$ & $\begin{array}{l}\text { Açıklama kanıt içermez } \\
\text { ya da uygun olmayan } \\
\text { kanıt içerir. }\end{array}$ & $\begin{array}{l}\text { Muhakeme içermez } \\
\text { yada uygun olmayan } \\
\text { muhakeme içerir. }\end{array}$ \\
\hline 2 & $\begin{array}{l}\text { Doğru ve tam iddia } \\
\text { içerir. }\end{array}$ & $\begin{array}{l}\text { Uygun olan kanıtlar } \\
\text { yanında uygun olmayan } \\
\text { kanıtlar içerir. }\end{array}$ & $\begin{array}{l}\text { Uygun olan } \\
\text { muhakemeler yanında } \\
\text { uygun olmayan } \\
\text { muhakemeler içerir. }\end{array}$ \\
\hline 3 & & $\begin{array}{l}\text { Uygun ancak yetersiz } \\
\text { kanıt içerir. }\end{array}$ & $\begin{array}{l}\text { Uygun ancak yetersiz } \\
\text { muhakeme içerir. }\end{array}$ \\
\hline 4 & & $\begin{array}{l}\text { Uygun ve yeterli kanıt } \\
\text { içerir. }\end{array}$ & $\begin{array}{l}\text { Uygun ve yeterli } \\
\text { muhakeme içerir. }\end{array}$ \\
\hline
\end{tabular}

Öğrenciler tarafından tamamlanan yazılı argümantasyon formları iki araştırmacı tarafından analiz edilmiş ve araştırmacılar arasındaki görüş birliği sağlanmıştır. İlk olarak beş yazılı argümantasyon formu iki araştırmacı tarafından analiz edilmiştir. Araştırmacılar arasında $\% 80$ görüş birliği sağlanmıştır. Araştırmalarda kodlamalar arasındaki uyumun $\% 70$ ve üzerinde olması güvenirlik için yeterli görülmektedir (Yıldırım ve şimşek, 2013). Bu nedenle araştırmacılar arasındaki görüş farklılıklarının da giderilmesinin ardından bir araştırmacı kalan formları kodlamıştır. Kodlamalar tamamlandıktan sonra her bir argüman öğesine ait frekans hesaplamaları yapılmıştır. Böylece sosyobilimsel konu içerikli alan gezilerinden önce ve sonra öğrencilerin ne kadar sıklıkla ve hangi seviyede argüman öğelerini sunduğu tespit edilmeye çalışılmıştır.

\section{BULGULAR}

Bu bölümde sosyobilimsel konu içerikli alan gezilerinin öğrencilerin argümantasyon nitelikleri üzerindeki etkisine ait bulgular yer almaktadır. Sosyobilimsel konu içerikli alan gezilerinin öğrencilerin argümantasyon niteliklerini nasıl etkilediğini tespit etmek amacıyla yazılı argümantasyon formları kullanılmıştır. Çalışmada her enerji santrali için farklı olmak üzere üç yazılı argümantasyon formu kullanılmıştır. Bu formlar enerji santrallerine düzenlenen alan gezisinden önce ve sonra tamamlanarak çalışma sonunda altı yazılı argümantasyon formu elde edilmiştir. Öğrencilerin yazılı argümantasyon formlarında sunduğu iddia öğesi 2, kanıt ve muhakeme öğesi 4 seviye ile değerlendirilmiştir. Seviye 1 en düşük niteliği, seviye 4 (iddia öğesi için seviye 2) ise en yüksek niteliği temsil etmektedir. Şekil 1'de her enerji santrali öncesi ve sonrasında tamamlanan yazılı argümantasyon formlarında yer alan iddia öğesine ait seviyelerin frekans değerleri sunulmuştur. 


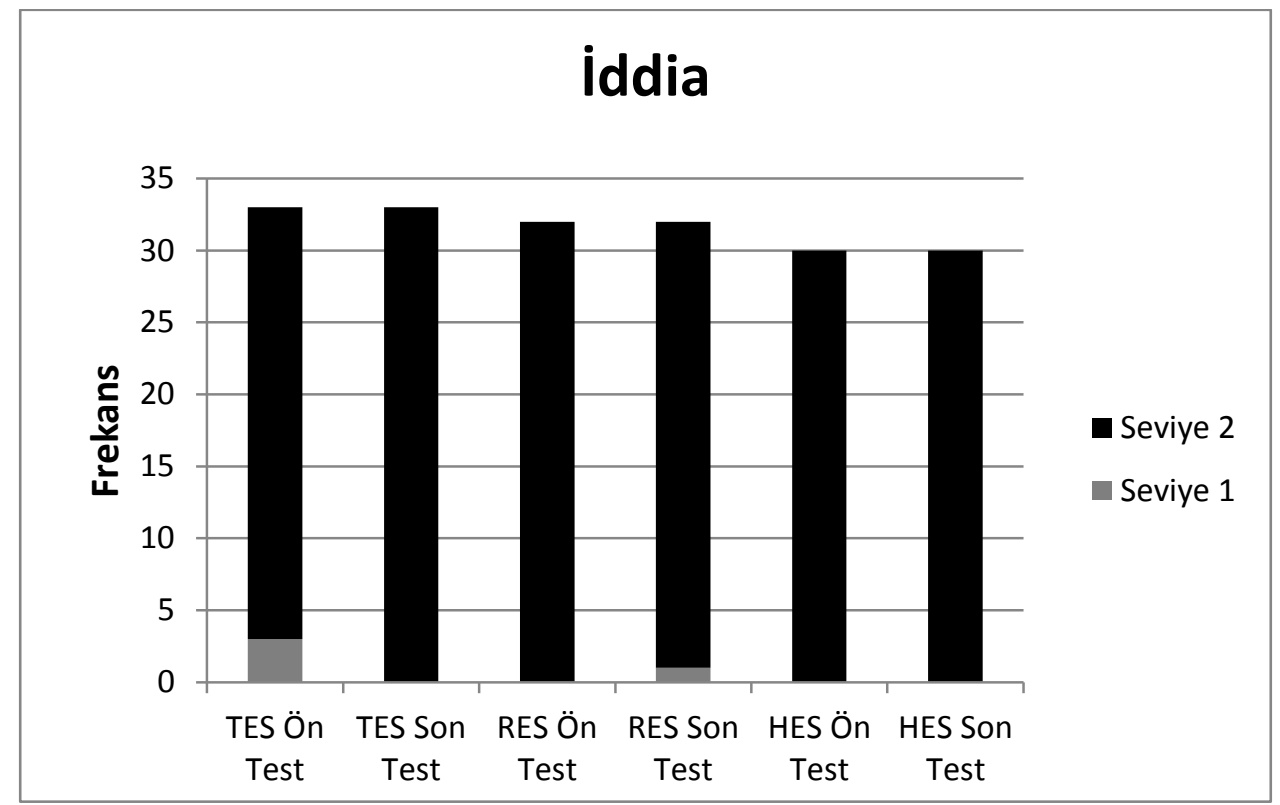

Şekil 1. Öğrencilerin sundukları iddia öğesine ait frekanslar TES: Termik enerji santrali, RES: Rüzgar enerji santrali, HES: Hidroelektrik enerji santrali

Şekil 1 incelendiğinde termik santrali gezisinden önce 3 öğrencinin 1. seviyede, 30 öğrencinin 2. seviyede iddia sunduğu görülmektedir. Rüzgâr santrali gezisinden önce tüm öğrenciler 2. seviyede iddialar sunabilirken gezi sonrasında 1 öğrenci 1 . seviyede iddia sunmuştur. Hidroelektrik santrali gezisi öncesi ve sonrasında ise tüm öğrenciler 2 . seviyede iddia sunabilmiştir. Genel olarak bakıldığında öğrencilerin alan gezileri öncesinde ve sonrasında büyük oranda 2. seviyede iddia sunabildiği görülmektedir.

Şekil 2'de 7. sınıf öğrencilerinin kanıt seviyeleri için termik, hidroelektrik ve rüzgâr santrallerine düzenlenen alan gezileri öncesine ve sonrasına ait frekans değerleri gösterilmektedir. 


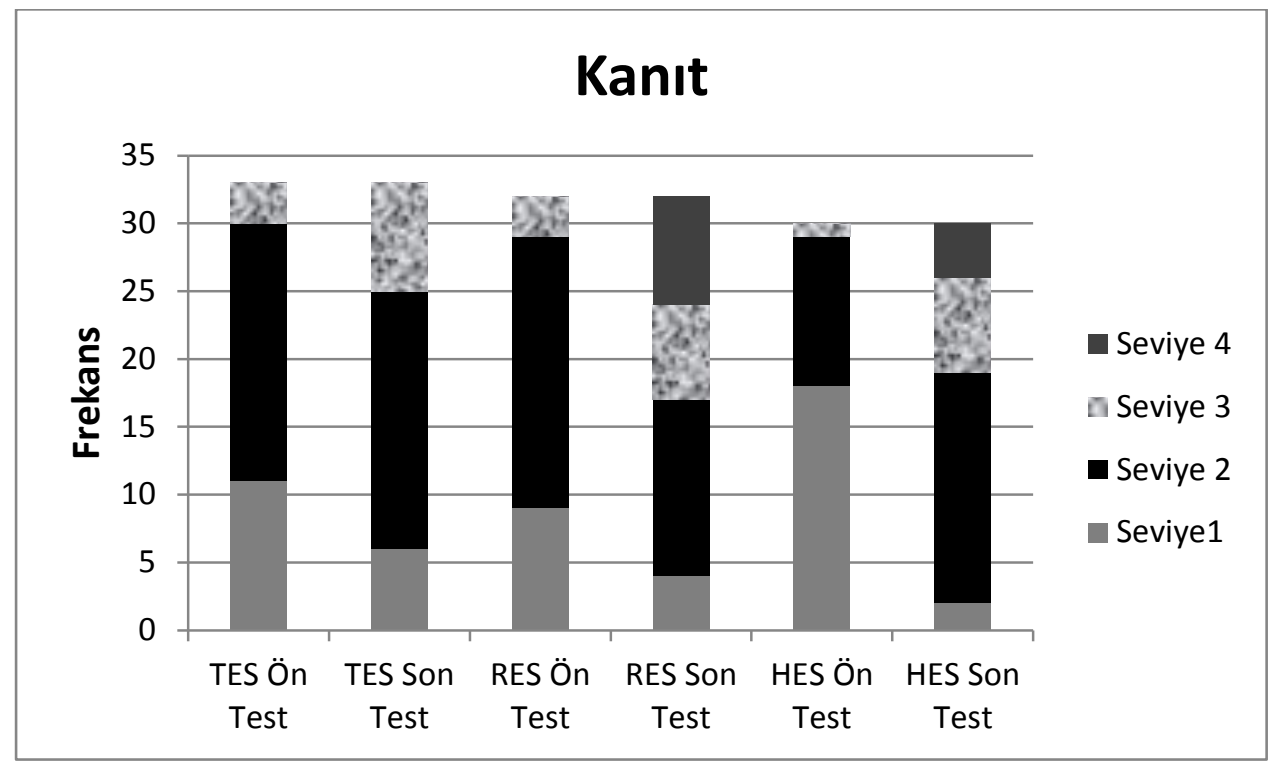

Şekil 2. Öğrencilerin sundukları kanıt öğesine ait frekanslar

Şekil 2 incelendiğinde termik santrali gezisinden önce 11 öğrencinin 1. seviyede, 19 öğrencinin 2. seviyede, 3 öğrencinin ise 3 . seviyede kanıt sunduğu görülmektedir. Termik santraline düzenlenen alan gezisi sonrasında ise 6 öğrenci 1 . seviyede kanıt sunmuş, 2. seviyede kanıt sunan öğrenci sayısı değişmemiş ve 8 öğrenci i 3. seviyede kanıt sunabilmiştir. Bu değerler sosyobilimsel konu içerikli alan gezilerinin öğrencilerin nitelikli kanıtlar sunmasını desteklediği şeklinde yorumlanabilir.

Rüzgâr santraline düzenlen alan gezisi öncesinde 9 öğrencinin 1. seviyede, 20 öğrencinin 2. seviyede ve 3 öğrencinin 3. seviyede kanıt sunduğu görülmektedir. Alan gezisi sonrasında ise 4 öğrencinin 1 . seviyede, 13 öğrencinin 2 . seviyede ve 7 öğrencinin 3 . seviyede kanıt sunduğu tespit edilmiştir. Ayrıca rüzgâr santraline alan gezisi düzenlenmeden önce hiçbir öğrencinin 4. seviyede kanıt sunamadığı, geziden sonra ise 8 öğrencinin bu seviyede kanıt sunabildiği görülmektedir.

Hidroelektrik santraline alan gezisi gerçekleştirilmeden önce 18 öğrencinin 1. seviyede, 11 öğrencinin 2. seviyede ve 1 öğrencinin 3. seviyede kanıt sunduğu görülmektedir. Örneğin 2 numaralı öğrenci hidroelektrik santrallerinin kurulmasını desteklediğini belirtmiş ve şu ifadeleri kanıt olarak sunmuştur. "Çünkü eski hali daha da kötüydü. Ama şimdiki çok güzel. Sosyal hayatta deniz yarışları yapılıyor, piknik yapılıyor". Bu ifadeler öğrencini iddiasını destekleyecek uygunlukta olmadığı için 0 puan ile değerlendirilmiştir. Hidroelektrik santraline yapılan geziden sonra ise 2 öğrencinin 1 . seviyede, 17 öğrencinin 2. seviyede ve 7 öğrencinin 3. seviyede kanıt sunabildiği görülmektedir. Ayrıca hidroelektrik santraline alan gezisi gerçekleştirilmeden önce hiçbir öğrencinin 4. seviyede kanıt sunamadığı, geziden sonra 4 öğrencinin bu seviyede kanıt sunabildiği görülmektedir. Örneğin bir öğrenci "hidroelektrik santrallerinin kurulmasını destekliyor musunuz?" sorusuna yönelik sunduğu iddiasını şu ifadeler ile desteklemiştir: "Hidroelektrik santralleri kurulmamalı. Çünkü doğaya vereceği zarar çoktur. Fazla yer kaplar, canlıların yaşadığı yerler yok oluyor ve bu doğanın dengesini bozuyor. Bir yandan bizim için önemli olan su kesiliyor. Su ihtiyaçlarımızı karşılayamıyoruz. Çok yer kapladığı nedeniyle ağaçlarımız da kesiliyor." Bu ifadede öğrenci hidroelektrik santrallerinin kurulmasını desteklemediği yönündeki iddiasını savunmak için canlıların yaşam alanlarının zarar görmesi, 
doğanın dengesinin bozulması, su sıkıntısı yaşanması, ağaçların zarar görmesi gibi kanıtlar sunmaktadır. Bu ifadeler 4. seviyedeki kanıt için gerekli olan uygunluk ve yeterlik kriterlerini karşılamaktadır.

Genel olarak Şekil 2'deki verilere bakıldığında termik, rüzgâr ve hidroelektrik santrallerine düzenlenen alan gezilerinden sonra 1 . seviyede kanıt sunan öğrenci sayısının azaldığı, 3. seviyede kanıt sunabilen öğrenci sayısının ise arttığı görülmektedir. Ayrıca santral gezisinden önce hiçbir öğrencinin 4. seviye olan en üst seviyede kanıt sunamadığı, gezilerden sonra öğrencilerin bu seviyede de kanıtlar sunabildiği görülmüştür. Bu nedenle sosyobilimsel konu içerikli alan gezilerinin öğrencilerin nitelikli kanıt sunmasını desteklediği söylenebilir.

Şekil 3'te ise öğrencilerin sosyobilimsel konu içerikli alan gezileri öncesi ve sonrasına ait muhakeme seviyelerine ile ilgili frekans değerleri verilmiştir.

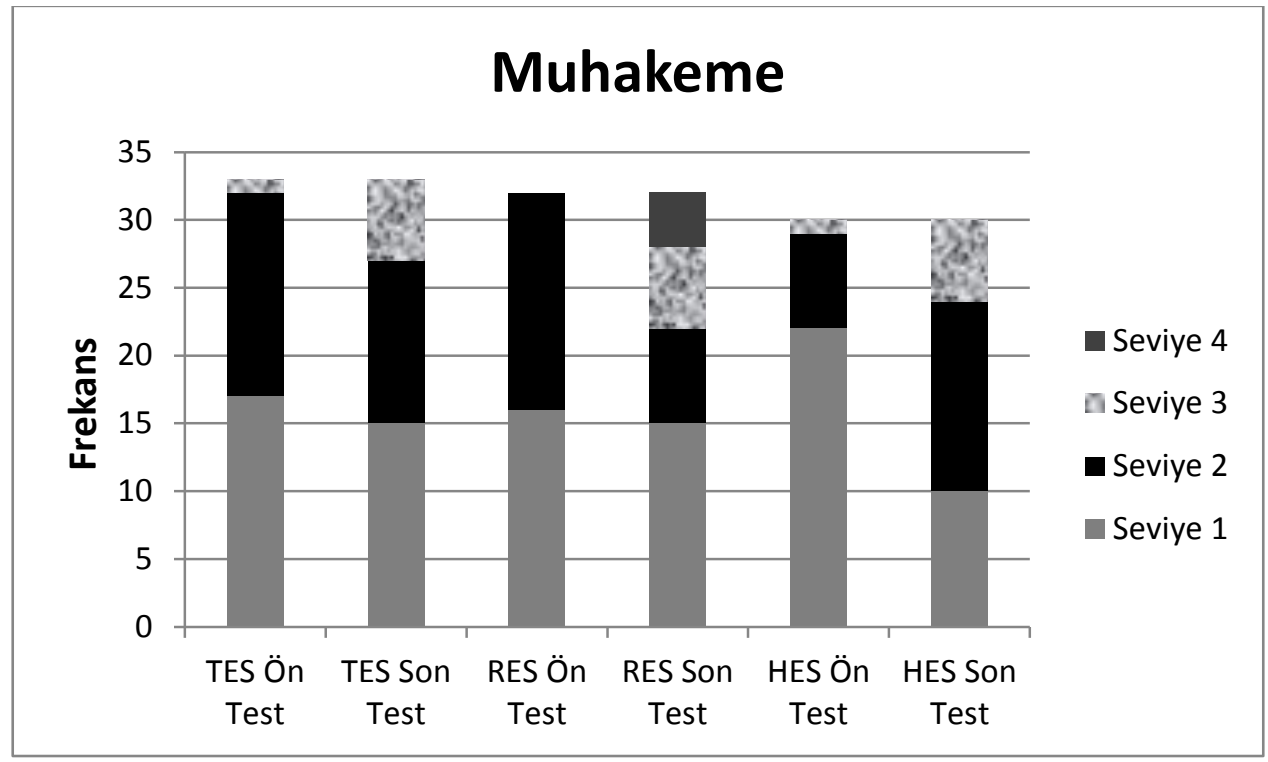

Şekil 3. Öğrencilerin sundukları muhakeme öğesine ait frekanslar

Şekil 3 incelendiğinde termik santraline gezi düzenlenmeden önce 17 öğrencinin 1. seviyede, 15 öğrencinin 2 . seviyede ve 1 öğrencinin 3 . seviyede muhakeme sunduğu görülmektedir. Gezi sonrasında ise 15 öğrencinin 1. seviyede, 12 öğrencinin 2. seviyede ve 6 öğrencinin 3. seviyede muhakeme sunduğu tespit edilmiştir.

Rüzgâr santrali gezisinden önce 16 öğrencinin 1. seviyede ve yine 16 öğrencinin 2 . seviyede muhakeme sunduğu görülmektedir. Geziden sonra ise 15 öğrencinin 1. seviyede, 7 öğrencinin 2. seviyede muhakeme sunduğu görülmektedir. Ayrıca gezi öncesinde hiçbir öğrencinin 3. ve 4. seviyede muhakeme sunamadığı, gezi sonrasında 6 öğrencinin üçüncü seviyede, 4 öğrencinin 4. seviyede muhakeme sunabildiği görülmektedir. Bu durum 2. seviyede muhakeme sunan öğrenci sayısındaki düşüşü açıklamaktadır. Gezi öncesinde 16 öğrenci 2. seviyede muhakeme sunarken gezi sonrasında bu öğrencilerin bazılarının muhakemelerini 3. ve 4. seviyeye ilerlettiği görülmektedir.

Hidroelektrik santraline gezi gerçekleştirilmeden önce 1 . seviyede 22,2 . seviyede 7 ve 3. seviyede 1 öğrencinin muhakeme sunduğu görülmektedir. Gezi sonrasında ise 10 öğrencinin 1. seviyede, 14 öğrencinin 2. seviyede ve 6 öğrencinin 3. seviyede muhakeme sunabildiği görülmektedir. Örneğin bir öğrenci hidroelektrik santrallerinin kurulmasını desteklemediğini belirtmiş ve iddiasını şu şekilde savunmuştur. "Su bizim için gerekli bir yaşam kaynağımız olduğu için hidroelektrik santrali kurulduğu zaman sularımız kesiliyor. Canlıların yaşam yerlerini 
yok ettiği için kurulmamalıdır. Çok yer kaplıyor ve ağaçlarımız kesildiği için kurulmamalıdır. Ağaçlar bizim için gereklidir ve oksijen kaynağımızdır. Ve bazı hayvanların yaşam yerleri bunun için kurulmamalıdır." Bu öğrenci suların kesilmesini bir problem olarak görmekte nedenini ise suyun yaşam kaynağı olmasına bağlamaktadır. Yine öğrenci ağaçların kesilmesini bir tehlike olarak nitelendirmekte ve bu tehlikeyi oksijen kaynağının yok edilmesi olarak açıklamaktadır. Bu nedenle öğrencinin sunmuş olduğu ifadeler 4 . seviyedeki muhakeme için gerekli olan uygunluk ve yeterlik kriterlerini sağlamaktadır.

Genel olarak Şekil 3'teki verilere bakıldığında termik, rüzgâr ve hidroelektrik santrallerine gerçekleştirilen alan gezilerinden sonra en düşük seviye olan 1 . seviyedeki muhakemeye sahip olan öğrenci sayısının düştüğü bunun yanı sıra 1. seviyeye göre daha nitelikli öğeleri temsil eden 2. ve 3. seviyedeki muhakemeye sahip öğrenci sayısının arttığı görülmektedir. Hatta bazı santral gezilerinden sonra (rüzgâr santrali) 4. seviyede de muhakemeler sunulabildiği tespit edilmiştir. Bu verilere dayanarak sosyobilimsel konu içerikli alan gezilerini öğrencilerin üst seviye muhakemeler sunmasını desteklediği söylenebilir.

\section{SONUÇ, TARTIŞMA VE ÖNERILER}

Bu çalışmanın amacı, sosyobilimsel konu içerikli alan gezilerinin ilköğretim öğrencilerinin argümantasyon nitelikleri üzerindeki etkisini tespit etmektir. Çalışma kapsamında termik, hidroelektrik ve rüzgâr santrallerine geziler düzenlenmiş, santral çevrelerinden alınan toprak numuneleri laboratuvarlarda incelenmiş ve santrallarla ilgili bilimsel modeller tasarlanmıştır. Ayrıca bu gezilerin öncesinde ve sonrasında öğrenciler tarafından yazılı argümantasyon formları tamamlanmıştır. Öğrencilerin yazılı argümantasyon formlarında sunmuş oldukları argümanlar Mcneill (2011) tarafından geliştirilen argümantasyon rubriğine göre analiz edilmiştir. Bu rubriğe göre iddia öğesi 2 seviye, kanıt ve muhakeme öğeleri 4 seviye üzerinden değerlendirilmiştir

Analizler sonunda öğrencilerin alan gezileri öncesi ve sonrasında sundukları iddiaların genellikle yüksek nitelikte olduğu tespit edilmiştir. Atabey ve Topçu (2013) tarafından öğrencilerin yazılı argümantasyon niteliklerindeki gelişimin araştırıldığı çalışmada da, öğrencilerin çalışma başında ve sonunda yüksek nitelikte iddialar sunabildiğini tespit etmiştir. Iddianın, öğrencilerin sunmakta en az zorlandığı öğe olarak tanımlanması (McNeill ve Martin, 2013) bu duruma gerekçe olarak gösterilebilir.

Çalışmada dikkat çeken diğer bir bulgu öğrencilerin kanıt niteliklerinin çalışma sonunda artmasıdır. Sosyobilimsel konu içerikli alan gezileri sonunda 1. seviyede sunulan kanıt sayısında düşüş görülürken 2., 3. ve 4. seviyedeki öğrenci sayısının sayısının arttığı tespit edilmiştir. Ayrıca rüzgâr enerji santraline düzenlenen gezi öncesinde 4. seviyede hiç kanıt sunulmaz iken gezi sonrasında 8 kişinin bu seviyede kanıt sunabildiği belirlenmiştir. Bu bulgular sosyobilimsel konu içerikli alan gezileri sonunda öğrencilerin daha nitelikli ve yüksek seviye de kanıt sunabildiklerini göstermektedir. Tal ve Kedmi (2006) tarafından gerçekleştirilen ve alan gezilerinin de yer aldığı sosyobilimsel konu temelli etkinliklerin ardından öğrencilerin iddiaları için daha fazla sayıda kanıt sunabildiği ve kanıtlarının niteliğini geliştirdiği ortaya konmuştur. Dolayısıyla mevcut çalışma sonuçlarıyla Tal ve Kedmi (2006) tarafından yapılan çalışma sonuçlarının paralellik gösterdiği görülmektedir. Bu duruma gerekçe olarak alan gezileri boyunca öğrencilerin sosyobilimsel problemi yerinde görmesi, problemin farklı boyutlarına dair gözlemlerde bulunabilmesi ve somut deneyimler edinmesi gösterilebilir. Ayrıca geziler boyunca uzmanlardan sosyobilimsel konu ile ilgili bilimsel bilgiler edinen öğrencilerin bu bilgilerini kanıt olarak kullandıkları görülmüştür. Uzmanların santral içerisinde farklı bölümleri gezerek elektrik üretim sürecini anlatması, öğrencilerin yaşayarak ve ilk elden deneyimler kazanarak öğrenmelerini sağlamıştır. Böylece öğrencilerin konuyla ilgili anlamlı öğrenmelere sahip 
olmasının desteklediği söylenebilir. Araştırma sonunda argümanları için bu bilgilerini kullanan öğrencilerin sundukları kanıt sayısının ve kalitesinin arttığı düşünülmektedir.

Çalışma sonunda elde edilen diğer bulgu öğrencilerin sundukları muhakemelerin niteliğinin artmasıdır. Alan gezileri öncesinde 1 . ve 2 . seviyede muhakeme sunan öğrenci sayısının geziler sonunda azaldığı, 3. ve 4. seviyede muhakeme sunan öğrenci sayısının arttığı görülmektedir. Zohar ve Nemet (2002) tarafından sosyobilimsel konu temelli ünite öğretiminin öğrencilerin argümanlarını nasıl etkilediğini tespit etmek amacıyla yapılan çalışma sonucunda da öğrencilerin iddiaları için birden fazla savunma sunabildiği tespit edilmiştir. Dolayısıyla mevcut çalışma ve Zohar ve Nemet (2002) tarafından yapılan çalışma sonuçlarına dayanarak sosyobilimsel konu içerikli etkinliklerin öğrencilerin muhakemelerini ve savunmalarını geliştirdiği söylenebilir. Alan gezilerinin öğrencilere gerçek yaşam deneyimleri kazandırdığı (Shakil ve diğ., 2011). Çevreyle birebir etkileşim halinde bulunmalarına katkı sağladığı (Orion ve Hofstein, 1991) bilinmektedir. Alan gezileri aracılığı ile edinilen somut deneyimler ve bilgiler, öğrencilerin konunun farklı boyutları ile yüzleşmelerini, böylece konuyla ilgili farklı argümanlar sunmalarını desteklemektedir (Fernandez-Manzanal, Rodriguez-Barreiro ve Casal-Jimenez, 1999). Alan gezisi boyunca konuyu derinlemesine anlayan öğrencilerin, değişkenler arasındaki ilişkileri açıklayabilmesi muhtemeldir. Mevcut çalışmada da alan gezileri ile öğrencilerin kanıtları ve iddiaları arasındaki ilişkiyi açıklayabilme, kanıtlarının niçin iddialarını desteklediğini ortaya koyabilme becerilerinin desteklendiği düşünülmektedir.

Literatürde sosyobilimsel konu içerikli öğretimlerin öğrencilerin argümantasyon niteliklerini desteklediğini ortaya koyan birçok çalışma mevcuttur (Dolan, Nichols ve Zeidler, 2009; Topçu ve Atabey, 2014). Örneğin Dawson ve Venville (2009) tarafından sosyobilimsel konu temelli etkinliklerin öğrencilerin argümantasyon ve informal muhakemelerini nasıl etkilediğini tespit etmek amacıyla gerçekleştirilen çalışma sonuçları da sosyobilimsel konu temelli etkinliklerin öğrencilerin argümantasyon niteliğini ve informal muhakemelerini geliştirdiği ortaya koymuştur. Mevcut çalışma literatürdeki bu çalışmalardan farklı olarak sosyobilimsel konu temelli öğrenme ortamlarında alan gezilerine odaklanmaktadır. Literatürde alan gezileri sosyobilimsel konu temelli öğrenme ortamlarında gerçekleştirilen etkinliklerden sadece biri olarak kullanılmakta iken (Tal ve Kedmi, 2006), mevcut çalışmada temel etkinlik olarak sosyobilimsel konu temelli alan gezilerine odaklanilmistir. Yani tüm öğretim ve etkinlikler sosyobilimsel konu temelli alan gezileri etrafında tasarlanmıştır. Bu nedenle çalışmanın alan gezileri ve sosyobilimsel konu temelli öğretimlerin birbirine entegre edilmesi ve alan gezilerinin tasarlanması noktasında literatüre farklı bir bakış açısı kazandıracağı düşünülmektedir. Böylece hem alan gezilerinin hem de sosyobilimsel konu temelli öğretimin çıktılarından faydalanılması söz konusu olacaktır. Mevcut çalışma ile de bu gezilerin öğrencilerin argümantasyon niteliklerini desteklediği de ortaya konmuştur. Gerçekleştirilen sosyobilimsel konu içerikli alan gezilerinin öğrencilere sorunla ilgili somut yaşantılar sunduğu ve konuyu daha iyi anlayabilmelerini, çeşitli boyutlarıyla ele alabilmelerini ve argümanlarını farklı açılardan savunabilmelerini desteklediği düşünülmektedir. Çünkü alan gezileri öğrencilere somut deneyimler edinme fırsatı vermekte ve çevre problemleri ile ilgili argüman sunmalarını desteklemektedir ( Fernandez-Manzanal ve diğ., 1999).

Ileriki çalışmalarda sosyobilimsel konu içerikli alan gezilerinin argümantasyon niteliği üzerindeki etkisini araştırmak için farklı sınıf seviyelerindeki öğrenciler ile çalışılabilir. Özellikle argümantasyon niteliğinin daha küçük yaşlarda geliştirilebileceği göz önünde bulundurulur ise alt kademedeki öğrenciler için sosyobilimsel konu içerikli alan gezileri düzenlenebilir. Örneklem değişikliğinin yanı sıra farklı sosyobilimsel konularda alan gezileri düzenlenerek bu gezilerin öğrencilerin argümantasyon nitelikleri üzerindeki etkisini araştıran yeni çalışmalar gerçekleştirilebilir. Ayrıca sosyobilimsel konu içerikli alan gezilerinin çevre eğitiminden ayrı bir 
uygulama olarak düşünülmemesi ve öğretmenlerin bu konuda cesaretlendirilmesi gerektiği düşünülmektedir.

\section{KAYNAKLAR}

Aktamış, H. ve Hiğde, E. (2015). Fen eğitiminde kullanılan argümantasyon modellerinin değerlendirilmesi. Mehmet Akif Ersoy Üniversitesi Eğitim Fakültesi Dergisi. 35, 136 172.

American Association for the Advancement of Science (AAAS). (1990). Benchmarks for science literacy, project 2061. New York: Oxford University Press.

Atabey, N. veTopçu, M. S. (2013). Exploring 7th grade students' quality of written argumentation: The impact of competing theories and predict-observe-explain strategies. European Science Education Research Association. 2-7 Eylül, NicosiaCybrus.

Berland, L. K. ve Reiser, B. J. (2009). Making sense of argumentation and explanation. Science Education. 93(1), 26-55.

Dawson, V. ve Venville, G. J. (2009). High-school students' informal reasoning and argumentation about biotechnology: An indicator of science literacy. International Journal of Science Education. 31(1), 1421-1445.

Dolan, T. J., Nichols, B. H. ve Zeidler, D. L. (2009). Using socioscientific issues in primary classes. Journal of Elementary Science Education. 21, 1-12.

Eastwood, J. L., Sadler, T. D., Zeidler, D. L., Lewis, A., Amiri, L. ve Applebaum, S. (2012). Contextualizing nature of science instruction in socioscientific issues. International Journal of Science Education. 34(15), 2289-2315.

Ekiz, S. O., Topçu, M. S. ve Aydeniz, M. (2013). Sixth grade students' quality of written argumentation and content knowledge: A case study. European Science Education Research Association. 2-7 Eylül, Nicosia-Cybrus.

Fernandez-Manzanal, R., Rodriguez-Barreiro, L. M., Casal-Jimenez, M. (1999). Relationship between ecology fieldwork and student attitudes toward environmental protection. Journal Research Science Teaching. 36(4), 431-453.

Hofstein, A., Eilks, I. ve Bybee, R. W. (2011). Societal issues and their importance for contemporary science education: A pedagogical justification and the state-of-the-art in Israel, Germany, and the USA. International Journal of Science and Mathematics 
Education. 9, 1459-1483.

Jimenez-Aleixandre, M., Rodriguez, M., ve Duschl, R. A. (2000). 'Doing the lesson' or 'doing science': Argument in high school genetics. Science Education. 84(6), 757- 792.

Karasar, N. (2000). Bilimsel araştırma yöntemi. Ankara: Nobel Yayınevi.

Knight, A. M. ve McNeill, K. L. (2012). Comparing students' written and verbal scientific arguments. National Association for Research in Science Teaching. 25-28 Mart, Indianapolis, IN.

McNeill, K. L., Lizotte, D. J., Krajcik, J. ve Marx, R. W. (2006). Supporting students' construction of scientific explanations by fading scaffolds in instructional materials. Journal of the Learning Sciences. 15(2), 153-191.

McNeill, K. L. ve Krajcik, J. (2009). Synergy between teacher practices and curricular scaffolds to support students in using domain-specific and domain-general knowledge in writing arguments to explain phenomena. Journal of the Learning Sciences. 18(3), 416-460.

McNeill, K. L. (2011). Elementary students' views of explanation, argumentation and evidence and abilities to construct arguments over the school year. Journal of Research in Science Teaching. 48(7), 793-823.

McNeill, K. L. ve Martin, D. M. (2013). Claims, evidence and reasoning. Froschauer, L. (Ed.), A year of inquiry: A data collection for elementary educatiors. (s. 170-175). Arlington, VA: Science Teachers Association Press.

National Research Council. (1996). National science education standards. Washington, DC: National Academy Press.

Naylor, S., Keogh, B. ve Downing, B. (2007). Argumentation and primary science. Research in Science Education. 37, 17-39.

Orion, N. ve Hofstein, A. (1991). The measurement of student's attitudes towards scientific field trips. Science Education. 75(5), 513-523.

Rebello, C. M. ve Barrow, L. H. (2013). Exploring the effects of scaffolding on college students' solutions and argumentation quality on conceptual physics problems. National Association for Research in Science Teaching. 6-9 Nisan, Rio Grande, Puerto Rico.

Sadler, T. D. (2004). Informal reasoning regarding socioscientific issues. a critical review of research. Journal of Research in Science Teaching. 41(5), 513-536.

Sadler, T. ve Donnelly, L. A. (2006). Socioscientific argumentation: The effects of content knowledge and morality. International Journal of Science Education. 28(12), 14631488.

Sadler, T. D., Friedrichsen, P., Graham, K., Foulk, J., Tang, N. ve Menon, D. (2015). Socioscientific Issue based education for three-dimensional science learning: derivation of 
an instructional model. National Association for Research in Science Teaching. 11-14 Nisan 2015, Chicago, Amerika.

Sandoval, W. A. ve Millwood, K. A (2005). The quality of students' use of evidence in written scientific explanations. Cognition and Instruction. 23(1), 23-55.

Shakil, A. F., Faizi, W., N. ve Hafeez, S. (2011). The need and importance of field trips at higher level in Karachi, Pakistan. International Journal of Academic Research in Business and Social Sciences. 2(1), 1-17.

Tal, T. ve Kedmi, Y. (2006). Teaching socioscientific issues: classroom culture and students' performances. Cultural Science Education. 1, 615-644.

Taş, A. M. (2012). Views of Turkish primary school teacher candidates on observation field trip to combined classes in rural settlements. Asian Social Science. 8(15), 142-146.

Topçu, M.S. ve Atabey, N. (2014). Sosyobilimsel konu içerikli alan gezilerinin ortaokul öğrencilerinin argümantasyon niteliğine etkisi. 11. Ulusal Fen Bilimleri ve Matematik Eğitimi Kongres. 11-14 Eylül, Adana, Türkiye.

Topçu, M. S., Muğaloğlu, E. Z. ve Güven, D. (2014). Fen eğitiminde sosyobilimsel konular: Türkiye örneği. Kuram ve Uygulamada Eğitim Bilimleri. 14(6), 2327-2348.

Topçu, M. S. (2015). Sosyobilimsel konular ve öğretimi. Ankara: Pegem Akademi Toulmin, S. (1958). The uses of argument. England: Cambridge University Press. van Eemeren, F. H. ve Grootendorst, R. (1996). A systematic theory of argumantation. Cambridge: Cambridge University Press.

Yahaya, J. M., Zain, A. M. N. ve Karpudewan, M. (2012). Understanding socioscientific issues in a low literate society for the achievement of the millennium development goals. World Academy of Science, Engineering and Technology. 72, 123-126.

Yıldırım, A. ve Şimşek, H. (2013). Sosyal bilimlerde nitel araştırma yöntemleri. Ankara: Seçkin Yayıncilık.

Zohar, A. ve Nemet, F. (2002). Fostering students' knowledge and argumentation skills through dilemmas in human genetics. Journal of Research in Science Teaching. 39(1), 35-62. 


\section{Ek. Yazılı Argümantasyon Formu}

Giderek artan dünya nüfusu, teknoloji alanındaki ilerlemeler, sanayinin gelişmesi enerji ihtiyacının da artmasına neden olmaktadır. Günlük yaşantımızın vazgeçilmez bir parçası haline gelen enerjinin yeterli miktarda üretilebilmesi için yeni enerji santrallerinin açılmasına intiyaç duyulmaktadır. Termik santraller enerjinin karşılanabileceği kuruluşlardan biridir. Ancak havaya salmış oldukları kirli gazlar çevrelerindeki ağaçların büyümelerini yavaşlatmakta, insanlarda solunum şikayetleri gibi hastalıklara neden olmaktadır Ayrıca termik santrallerde buhar üretme, soğutma ve temizleme işlemleri için önemli miktarda su kullanılmakta, atık sular da tekrar kaynağa geri döndürülmektedir. Bu durumda da su ve toprak kirliliği oluşmaktadır. Termik santrallerinin avantaj ve dezavantajları nedeniyle, bu santrallerin kurulması toplumdaki bazı kesimler tarafından desteklenmekte iken bazı kesimlerce desteklenmemektedir.

-Sizce termik santralleri kurulmalı mı kurulmamalı mı?

-iddianızı kanıtlayınız. İddianızı destekleyecek bilgilerinizi, gözlemlerinizi, yaşantılarınızı yazınız.

- Termik santrallerinin kurulması ya da kurulmaması yönündeki iddianız ile sunduğunuz kanıtlar arasında bağlantı kuran cümleler yazınız. Bu cümleler sunduğunuz kanıtların niçin iddianızı desteklediğini açıklamalı. 


\section{SUMMARY}

This paper presents the effects of socioscientific based field trips on middle school students' argumentation qualities. Thirty-one 7th grade students participated in the study. Data collection tools prepared by researchers were written argumentation forms for thermal, wind and hydroelectiric power plants. Students completed these forms as pre and post tests. The researchers analyzed written argumentation forms according to framework of Mcneill (2001). Focus socioscientific issue of the study was energy production. Therefore students participated there field trips to power plants through study. Participiants visited thermal, power and hydroelectric power plants and similar activites were realized in the same order for each power plant. In the context of the field trips, experts explained the energy production process to students. Then students collected soil samples to define the effects of energy production process on environment. A chemical engineer and his crew analyzed these samples in a state university and students discussed the results. Afterwards students planted some areas around of power plants. Following the completition of field trips students designed and developed their power plant models. As the last activities, students completed written argumentation forms and argued about the construction of new power plants. For the data analyses the frequncies were calculated for each level of argument compenents (claim, evidence, reasoning) before and after field trips. Results indicated that most of the students could present second level claims before and after field trips. In adddition, results showed that the number of students presented claims at first level decreased and the number of students presented claims at third level increased after field trips to thermal power plant. The similar results were valid for wind and hydroelectric power plants. It was seen that the number of evidences at first level decreased and the number of evidences at second, third and fourth level increased after field trip to wind and hydroelectiric power plants. Besides there were any students who could present evidences at fourth level before field trip but 8 students could present evidences at fourth level after field trip to wind power plant. These results showed that students could present better quality evidences after socioscientific based field trips. The another result found in the study was the increase of reasoning qualities. The number of reasonings presented at first and second level decreased and the reasonings presented at third and fourth level increased. These results might be interpreted that socioscientific based field trips support students in terms of presenting high quality reasonings. The increase of the number of claims, evidences and reasonings at high levels showed that socioscientific based field trips developed students' arguments qualities. This may be due to the fact that field trips provide concrete experiences. These experiences allow students with a better understanding of the topic, handling the subject in various dimensions and defending their arguments from different angles. Future research might focus on students at different grade levels to explore the effects of socioscientific based field trips on students' argumentation qualities. In addition to sample change, the effects of field trips on different socioscientficis issues might be studied. Socioscientific based field trips should not be considered separate from environmental education and teachers should be encouraged in this regard. 